\title{
Understanding Levels of Prospective Science Teachers on the Nature of Science
}

\author{
Suleyman Yaman ${ }^{1, *}$, Hasret Nuhoglu ${ }^{2}$ \\ ${ }^{I}$ Karaelmas University, Eregli Education Faculty, Science Education Department, Zonguldak, Turkey \\ ${ }^{2}$ Maltepe University, Istanbul, Turkey
}

Received 8 August 2010 - Accepted 22 September 2010

\begin{abstract}
The aim of this study is to determine whether the understandings levels of prospective science teachers on the nature of science are dependent on differences in grade level and gender. This study utilizes VOSTS scale, which was developed by Aikenhead and Ryan, and adapted by Chan in order to determine viewpoints of prospective teachers on the nature of science. Eighteen multiple-choice questions from this scale were translated and adapted into Turkish from English by researchers, who also conducted a preliminary work on the validity and reliability of the scale. The adapted scale was applied to 80 prospective science teachers, who were not included in the sample of this study and the reliability coefficient of the scale was found to be 0.81 . Then the scale is applied to 201 prospective teachers who are enrolled in the science education program. The statistical analysis of the results demonstrated that while views of the prospective science teachers on nature of science are not significantly correlated with differences in grade level and gender, there were significant variations among these views. In this study, it was determined that prospective teachers had certain misconceptions on nature of science with respect to specific issues including hierarchical relationships between concepts of hypothesis, theory, law, and universal scientific method; that they relied predominantly on positivist paradigm; and that they espoused the traditional approach to science in understanding and interpreting nature of science.
\end{abstract}

Key words: Science Education, The Nature of Science, Scientific Literacy, Skills of Scientific Processing

\section{Introduction}

The concept of the nature of science (NOS) became increasingly important in science education after 1950s. It proved to be a particularly significant issue during many educational reforms in recent years (Akerson, Buzzeli and Donnelly, 2010; McComas, Clough and Almazroa, 2006). Many science educators offered various suggestions and explanations on the instruction of NOS. These suggestions and explanations basically converge on relevance of points like scientific literacy, public image of concepts of science, and different ways of contributing to student-centered public education (Chen, 2001). The shared result of these studies, which aimed to increase the level of intelligibility of science, is that divergence of opinions between scientists has increased even further due to division of science into subcategories, (Snow, 2001). This situation leads each branch of science to create its own paradigm (Kuhn, 1982).

\footnotetext{
${ }^{*}$ Corresponding author: Phone: +9037232338 70,

ISSN: 1306-3049, Email: syaman@zku.edu.tr (C) 2010
} Fax: +9037232368 93, 
Along with the increasing specialization of fields of science, interaction and communication between related fields has weakened, and scientific practice has become increasingly difficult to understand for people working on different fields of science. Thus, each individual may only notice the issues and problems in the field he or she is interested in (Snow, 2001). As a reflection of this situation, a person working in a specific branch of science has no or very little information about other branches of science, which significantly affects the universality of science. In addition, people working on different areas may consider other branches of science as unimportant. By being able to teach students that all branches of science are necessary to improve the quality of human life, it may be possible to reduce the prevalence of such misguided approaches. In order for science to be useful to humanity, it is necessary to ensure that students have a like for science in general; to demonstrate that science is a general community of knowledge to benefit everyone; to explain the relationship between the different branches of science; and to teach how science should be learned. In order to do that, students should be provided with experiential opportunities to understand the NOS. In the process, it will be helpful to lead students towards specific studies which would initiate them to explore different science topics, so that they may acquire the skills mentioned above (Bianchini and Colburn, 2000). This requires that students have the basic knowledge and skills about the foundations of the NOS.

The NOS indicates not only products of science (like concepts, theories, laws) and derivation of scientific processes based on the nature of scientific knowledge (activities like observation and inference), but also scientific studies (Meichtry, 1993). One of the most basic elements of understanding the NOS is to be "science literate". Science literacy involves students' comprehension of concepts, principles, theories and processes of science, as well their awareness of the complex relationships between science, technology and society (AbdEl-Khalick, Bell and Lederman, 1998). In this context, the NOS are defined as the epistemology of science, methods of information-acquisition and a system of values and beliefs specifically for the development of science (Lederman, 1992). Special concepts of science should also be included in the instruction of the NOS beyond widely adopted collections of information (Bell and Lederman, 2003). Such collections of information are generally considered skills of scientific processing. Skills of scientific processing and the NOS are always in interaction with each other. It is extremely important to teach these skills to students (Bell, Lederman and Abd-El-Khalick, 2000). At the same time, the fact that this information may undergo changes over time along with the development of science is an issue that particularly calls focusing on (Lederman, Abd-El-Khalick, Bell and Schwartz, 2002). It is widely accepted that the students who acquire skills of scientific processing will have a sounder grasp of these basic properties of science. Skills of scientific processing are actually the reflection of scientific behavior and of the regulation of talents that are appropriate and applicable for different science disciplines. Students utilize their skills of scientific processing in accessing to information by asking questions, making observations, doing measurement, collecting data, interpreting data, estimating the effects of a variable, hypothesis testing and formulating, making experiments, drawing conclusions from observations, linking to the other fields. This type of study leads students to learn the laws, principles, generalizations and concepts that are necessary for acquiring the scientific thinking skills (Renner and Marek, 1990). Understanding the concepts of science refers to the skills to apply scientific processing, and therefore to the nature of science. Teachers and prospective teachers who have these skills will promote more effective methods in making the students understand the world and improving the quality of science education in our country. In order to correct the failures in international examinations like TIMSS and PISA, particularly in the field of science (Bağc1Kılıç, 2002; Berberoğlu and Kalender, 2005), both teachers and prospective teachers should have the required skills and knowledge, because it is not possible for a person to teach what 
he or she did not understand (Abd-El-Khalick and Lederman, 1999). In our constantly changing and developing world, prospective teachers are expected to gain these skills and to transfer them to students in the in-service process. Development of these skills of prospective teachers will be possible largely through the education they receive in their pre-service period.

According to the constructivist approach, creation of educational settings that are appropriate for the content of new academic curriculum is directly related to how science teachers and prospective teachers perceive the nature of science. Various researches demonstrated the resistance of teachers (based on the irrevocable of scientific knowledge) and ensuing problems that emerge in the applications of the constructivist approach (Donnelly, 1999; Gallagher, 1991; Tsai, 2002). As a reflection of this situation, it is debatable how the teachers who demonstrate resistance on developing themselves can be positively effective in the development of their students. Studies in our country on the NOS demonstrates that students, teachers and prospective teachers are largely inadequate (Balk1, Çoban and Aktaş, 2003; Kurt, Kaya, Ateş and Kılıç, 2009; Kılıç, Sungur, Çakıroğlu and Tekkaya, 2005; TunçŞahin and Köksal, 2010; Turgut, 2009). Considering the fact that prospective science teachers' understanding level on the NOS will directly affect the quality of science education, there is urgent need for more information and research on the issue in order to be able to compete with developed countries. By a comprehensive assessment of the prospective science teachers' understanding level on the NOS, this study aims to contribute to the development of education of teachers in general, beyond field training. In this context, the aim of this study is to reveal continuities or variations based on grade level and gender differences among current prospective teachers (who are being instructed on science education) with respect to their understanding level on the NOS.

\section{Method}

\section{Sample}

Research was conducted with the participation of 201 prospective teachers studying at the Department of Science Teacher Education, Kırşehir Education Faculty. Distribution of participants according to grade level is as follows: in grade 1, 64; in grade 2, 55; in grade 3, 48; and in grade 4, 34 prospective teachers. The mean age of prospective teachers is 20.3, with 101 of them being female and 100 of them male.

\section{Data Collection Tool}

In this study, a specific version of the Science Technology and Society (VOSTS) viewpoint scale (Aikenhead and Ryan, 1992) was used, as adapted by Chen (2001). Based on the existing literature, Chen re-developed the VOSTS scale that consisted of 114 questions into 18 questions and applied it to prospective teachers in his study. This scale was adapted into Turkish by researchers in order to determine the prospective teachers' understanding level on the NOS. This version of the scale was reviewed for this study by three faculty members who are experts on the subject area and on field education. Experts emphasized mainly "scope" and "intelligibility" in their reviews. Re-organized according to expert opinion, the measuring tool was applied to 80 prospective teachers who were not included to the original sample, in order to determine its structural validity and level of reliability. At the end of this pilot study, it was seen that some questions of the measuring tool were not properly understood by prospective teachers or were left blank. Re-designing these specific questions by taking expert opinion, the subsequent version of the scale was applied to 201 students, who constitute the actual application group. In order to determine the level of reliability of the measurement tool, data obtained in the pilot study were analyzed with the 
split-half method and internal consistency coefficient was determined to be 0.81 . Students were given 40 minutes to provide answers for the scale.

Scale questions were configured as multiple-choice questions on explanations of specific topics related to the NOS. Students were asked to choose one item in every question or to indicate their own views if they were not content with any of the options offered to them.

Sample question:

Scientific observations made by competent scientists will usually be different from each other, if these scientists believe in different theories.

Choose an item from below that best represents your position, ranging between $A-H$.

A) Yes, because scientists do experiments with different methods and draw attention to different points.

B) Yes, because scientists think in different ways and this will alter their observations.

C) Scientific observations will not vary too much due to different theories. If the scientists are indeed competent their observations will be similar.

D) No, because observations are as accurate as possible. This demonstrates how much science has advanced.

E) No, observations are exactly what we see and nothing else; they are facts.

F) I don't understand.

G) I don't have enough knowledge about this subject to make a choice.

H) None of these choices fits my viewpoint. My viewpoint is

Each question or item in the scale contained specific propositions or judgments related to the NOS; and prospective teachers were asked whether or not they supported these propositions or judgments. The ranges of responses provided in every question were grouped into three categories of choices: "supporting", "not supporting" and "no opinion". It has been assumed that those who chose A, B or C supported the proposition; those who chose D or E did not support the proposition; those who chose F could not analyze the proposition properly; those who chose I did not have adequate information about it. If the respondents had different opinions of their own about the subject they were asked to select $\mathrm{H}$ and give an open-ended response. This option would be marked and grouped by categorizing it appropriately.

\section{Data analysis}

Data analysis was conducted with SPSS. In the analysis of the data obtained by application of the scale, percentages were used, while for frequency analysis chi-square statistics were used. Understanding level of students on the NOS was dependent variable, grade level and gender were independent variables. In the chi-square statistical analysis, significance was tested as 0.05 .

\section{Results}

In this part, the understanding levels of prospective science teachers on the NOS has been analyzed and interpreted according to grade level and gender variables.

Problem 1. Is there a significant difference between the understanding levels of prospective science teachers enrolled in different grade levels of the Department of Science Teacher Education? 
Table 1. The distribution of views of prospective teachers about the NOS according to grade level

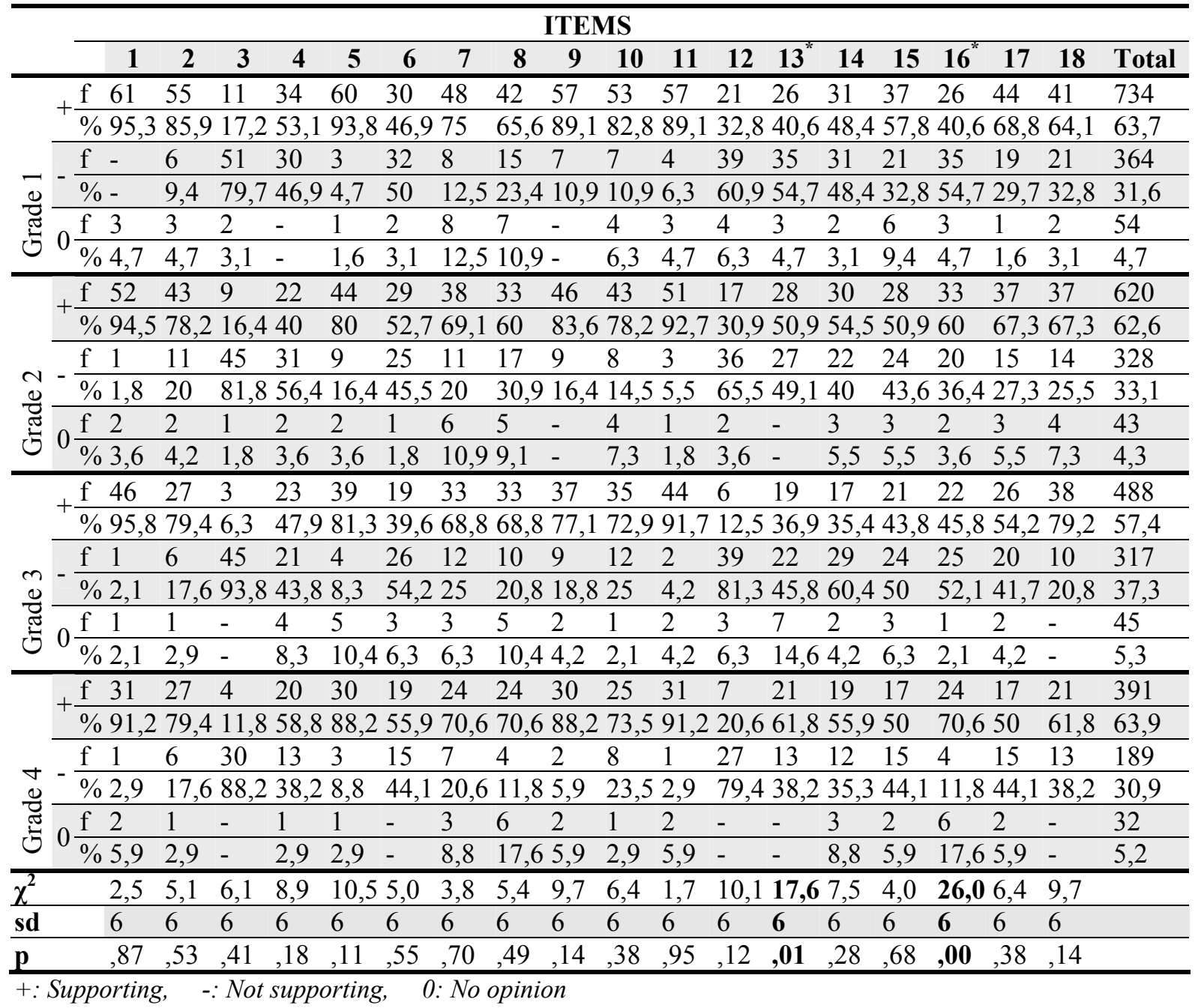

It has been determined that there was not a significant difference among prospective teachers from different grade levels with respect to the $1^{\text {st }}$ question on "observation of nature". Almost all of the prospective teachers claimed that differences in scientific observations by different scientists stem from the fact that they are using different theories, and that this is one of the basic features of scientists. In addition, the proportion of prospective teachers who did not support the proposition in the question has been quite low.

Responses to the $2^{\text {nd }}$ question on the "nature of scientific models" did not demonstrate a significant difference among prospective teachers from different grade levels. $80 \%$ of prospective teachers identified knowledge on the development and use of scientific models with science and scientists. The rate of those who did not support this view or failed to express any opinion was observed to be very low.

In the $3^{\text {rd }}$ question on "the nature of classification schemes", prospective science teachers did not support the idea that scientists classify information based on natural methods. While prospective teachers supported the idea that there are various methods of classifying events, facts and concepts, it has been determined that their viewpoints on this issue did not demonstrate a significant level of variation among different grade levels. 
In response to the 4th question about the "mutability of scientific knowledge" approximately half of all the prospective teachers defended the idea that new scientists develop new theories by coming up with new data in the light of older data. Approximately $40 \%$ of the prospective teachers claimed that they lacked adequate information about the subject. Moreover, it has been determined that there was not a significant difference on this issue between opinions of different grade levels.

With respect to "relations between hypotheses, theories and laws", about $85.8 \%$ of the prospective teachers argued that scientific ideas develop from hypotheses into theories. They stated that this is because hypotheses are tested with experiments, and if experiments yielded correct results, hypotheses would become theories. Despite lack of significant levels of variation among different grade-levels of prospective teachers, it has been observed that firstgrade prospective teachers display the highest rate of support for this idea $(93.8 \%)$.

It has also been determined that responses to the $6^{\text {th }}$ question on "the role of assumptions in the development of new theories and laws" by prospective teachers in different grade levels did not differ significantly. The percentages of prospective teachers who supported and did not support this idea were very close to each other. While approximately half of prospective teachers argued that "correct assumptions must be made for correct theories and laws", the other half defended that "some of the great discoveries could be made possible by falsification and learning about its wrong assumptions".

Based on the chi-square analysis of responses, there is no significant difference between prospective teachers from different grade levels in their responses to 7th and 8th questions. These questions contain explanations about "the criteria for superiority of scientific ideas". Based on the responses of prospective teachers, it is observed that in their viewpoint, qualified theories should be clear and simple, and, in parallel, simple equations (like Einstein's equation $\mathrm{E}=\mathrm{m} \cdot \mathrm{c}^{2}$ ) reveal the meaning of nature, as well as its beautiful aspects. The proportion of prospective teachers who defend this idea is higher than the proportion of prospective teachers who do not.

Prospective teachers did not demonstrate significant differences according to their grade level in their understanding level on "the role of the scientific method in scientific research". When responses of prospective teachers to the $9^{\text {th }}$ question were examined, it was seen that more than half of them defended that "scientists follow the steps of scientific method, since scientific method ensures valid, logical and precise results". The proportion of students who supported the idea that sustained scientists may also use methods beyond the acknowledged scientific methods was approximately $13 \%$. Prospective teachers propounding this view held that scientists must use their creativity and come produce different ideas.

It has also been determined that responses to the $10^{\text {th }}$ question on "the role of communication for scientific method" do not differ according to grade levels. The proposition "although scientists do not conduct their research in a logical order, they present the articles they publish in journals in a logical order to offer other scientists a better understanding" has been supported by $76.0 \%$ of prospective teachers. The proportion of prospective teachers supporting the opinion that scientific studies should be conducted according to a logical order is $20 \%$. According to these results, it could be argued that for prospective teachers, communication has an important role in scientific studies.

In $11^{\text {th }}$ question on "uncertainty and accuracy of scientific information" prospective teachers predominantly hold that "measurement errors may always happen" and that "although scientists use mathematics in order to reach facts, they may have to resort to estimates for possible situations, especially if the impact of unexpected events is to be considered". On the contrary, the proportion of those who believe that mathematics gives 
accurate results $100 \%$ is quite low $-4.25 \%$. Moreover it has been observed in relation to this particular question that, views of teachers in the study from different grade levels did not differ significantly.

The question on "verification of solutions (which scientists offer in their work) by experiments" that was addressed to prospective teachers is actually about skills of logical inquiry. Views of prospective teachers about this question do not differ significantly in terms of differences in grade level. $71.7 \%$ of prospective teachers do not hold that "a scientist, who ascertains the possibility of lung cancer on people working with asbestos, needs to conclude (as a result of this research) that asbestos causes lung cancer". Prospective teachers have gone into a process of logical inquiry by arguing that such a conclusion requires further research, and that perhaps what actually caused cancer might be interaction of asbestos with other elements. The proportion of prospective teachers who hold that "if a scientist finds in his/her study that there are high amounts of asbestos on people with lung cancer, this is enough to reach the conclusion that asbestos causes cancer" is approximately $20 \%$ of.

Responses to the 13th question, which brings out views of prospective teachers about "basic assumptions of all sciences" demonstrated significant differences according to the grade level $\left(\chi^{2}(6)=17 ; 6 ; p<0.01\right)$. While the proposition "science is established on the assumption that natural life cannot be changed by supernatural powers" was supported by teachers in $2^{\text {nd }}$ and $4^{\text {th }}$ grades, it was not supported by those in $1^{\text {st }}$ and $3^{\text {rd }}$ grades. Those who supported this view argued that "supernatural powers are beyond scientific proof" and that "if there were such a thing scientific facts would have been changed any time through this power". On the other hand, those who did not support this idea argued that "since science does not know anything about the nature, natural sciences should be open to the possibility that supernatural powers may be able to change the world".

In the contents of the $14^{\text {th }}, 15^{\text {th }}$ and $16^{\text {th }}$ questions, there are propositions on the "epistemological structure of scientific knowledge". While views of prospective teachers on this issue studying in different grades did not show significant differences on $14^{\text {th }}$ and $15^{\text {th }}$ questions, significant differences were observed in the $16^{\text {th }}$ question $\left(\chi^{2}(6)=26 ; p<0.01\right)$. With respect to the proposition as to "whether scientists invent or discover scientific laws and hypotheses" the rates of proponents of both views were respectively $48.55 \%$ for $14^{\text {th }}$ question and $50.63 \%$ for $15^{\text {th }}$ question. That means that prospective teachers held both of these two ideas in equal terms. In $16^{\text {th }}$ question, fourth-grade prospective teachers displayed the highest rate of support for the idea that scientists invent scientific theories with $70.6 \%$, whereas firstgrade prospective teachers had the lowest rate, $40.6 \%$. There are significant differences between the views of fourth-grade prospective teachers who held that scientists invented their discoveries, and those of first-grade prospective teachers who held that these inventions were already present, and that scientists only revealed them.

Responses to the 17th question on the "paradigm of interdisciplinary concepts" by prospective teachers from different grade levels did not demonstrate significant differences. In this question, it has been proposed that "scientists in different fields look at the same thing from different points of view (for example, $H+$ causes chemists to think of acidity and physicists to think of protons)". The question aimed to reveal the views of prospective teachers about this premise, which meant that "scientific ideas differ depending on the work carried out by scientists in different fields". According to the data obtained, more than half of the prospective teachers believe that scientific ideas depend on the scientific points of view or the habits of scientists. The proportion of those who did not support this view was approximately $35 \%$. The prospective teachers who held this opposing view were arguing that 
scientists must develop new methods in order to understand other fields and branches of science.

It has been determined that responses to 18th question on the "compatibility of interdisciplinary concepts" did not differ significantly. The view that "a scientist may interpret other fields of science differently" has been supported by nearly $70 \%$ of prospective teachers. 1/4 of teachers defended that "an idea has to be understood by a scientist regardless of its content".

Problem 2. Does the understanding level of prospective science teachers (studying at science education programs) on the NOS significantly differ according to gender?

Table 2. The distribution of views of prospective teachers about the NOS according to gender

\begin{tabular}{|c|c|c|c|c|c|c|c|c|c|c|c|c|c|c|c|c|c|c|c|}
\hline \multicolumn{20}{|c|}{ ITEMS } \\
\hline & 1 & 2 & 3 & 4 & 5 & $6^{*}$ & 7 & 8 & 9 & 10 & 11 & 12 & 13 & 14 & 15 & $16^{*}$ & 17 & 18 & Total \\
\hline \multirow{6}{*}{ 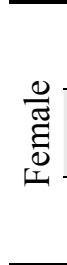 } & + f 98 & 82 & 15 & 43 & 89 & 38 & 73 & 64 & 88 & 74 & 92 & 22 & 54 & 80 & 82 & 76 & 59 & 74 & 1203 \\
\hline & $\% 97,0$ & 0 81,2 & 14,9 & 42,6 & 88,1 & 37,6 & 72,3 & 63,4 & 87,1 & 73,3 & 91,1 & 21,8 & 53,5 & 79,2 & 81,2 & 75,2 & 58.4 & 73.3 & 66,2 \\
\hline & f 1 & 16 & 83 & 53 & 8 & 61 & 18 & 24 & 12 & 22 & 5 & 77 & 44 & 17 & 18 & 24 & 39 & 27 & 549 \\
\hline & $\% 1,0$ & 15,8 & 82,2 & 52,5 & 7,9 & 60,4 & 17,8 & 23,8 & 11,9 & 21,8 & 5,0 & 76,2 & 43,6 & 16,8 & 17,8 & 23,8 & 38.6 & 26.7 & 30,2 \\
\hline & $\mathrm{f} 2$ & 3 & 3 & 5 & 4 & 2 & 10 & 13 & 1 & 5 & 4 & 2 & 3 & 4 & 1 & 1 & 3 & 0 & 66 \\
\hline & $\% 2,0$ & 3,0 & 3,0 & 5,0 & 4,0 & 2,0 & 9,9 & 12,9 & 1,0 & 5,0 & 4,0 & 2,0 & 3,0 & 4,0 & 1,0 & 1,0 & 3.0 & 0.0 & 3,6 \\
\hline \multirow{6}{*}{$\frac{0}{\pi}$} & $+\mathrm{f} 92$ & 85 & 12 & 56 & 84 & 59 & 70 & 68 & 82 & 82 & 91 & 29 & 54 & 77 & 74 & 76 & 65 & 63 & 1219 \\
\hline & $\% 92,0$ & 85,0 & 12,0 & 56,0 & 84,0 & 59,0 & 70,0 & 68,0 & 82,0 & 82,0 & 91,0 & 29,0 & 54,0 & 77,0 & ) 74,0 & 76,0 & 65.0 & 63.0 & 67,7 \\
\hline & f 2 & 11 & 88 & 42 & 11 & 37 & 20 & 22 & 15 & 13 & 5 & 64 & 41 & 17 & 18 & 16 & 30 & 31 & 483 \\
\hline & $\% 2,0$ & 11,0 & 88,0 & 42,0 & 11,0 & 37,0 & 20,0 & 22,0 & 15,0 & 13,0 & 5,0 & 64,0 & 41,0 & 17,0 & 18,0 & 16,0 & 30.0 & 31.0 & 26,8 \\
\hline & $0 \mathrm{f} 6$ & 4 & 0 & 2 & 5 & 4 & 10 & 10 & 3 & 5 & 4 & 7 & 5 & 6 & 8 & 8 & 5 & 6 & 98 \\
\hline & $\% 6,0$ & 4,0 & 0,0 & 2,0 & 5,0 & 4,0 & 10,0 & 10,0 & 3,0 & 5,0 & 4,0 & 7,0 & 5,0 & 6,0 & 8,0 & 8,0 & 5.0 & 6.0 & 5,5 \\
\hline$\chi^{2}$ & 2,5 & 1,1 & 3,5 & 4,3 & 0,7 & 11,1 & 0,2 & 0,6 & 1,5 & 2,7 & 0,2 & 4,9 & 0,6 & 0,5 & 5,9 & $\overline{7,0}$ & 2,0 & $\overline{7,2}$ & \\
\hline sd & 2 & 2 & 2 & 2 & 2 & 2 & 2 & 2 & 2 & 2 & 2 & 2 & 2 & 2 & 2 & 2 & 2 & 2 & \\
\hline p & ,28 &, 57 & , 18 &, 12 & ,70 & ,01 & ,92 & ,74 &, 46 & ,26 &, 89 & ,09 & ,74 &, 80 &, 05 &, 03 & ,38 & ,03 & \\
\hline
\end{tabular}

There is no significant difference between responses of prospective teachers with different genders to the $1^{\text {st }}$ question on the "nature of observation". Almost all of both female and male prospective teachers held that scientists made observations using unusual methods.

There is also no striking variation among responses by male and female students on the proposition that "models developed by scientists are identical to the natural processes they are modeling". About $4 / 5$ of the prospective teachers from both groups of students held that models of scientists are identical to reality as much evidence and scientific facts have shown. The ratio of prospective teachers who do not support this view is approximately is $13 \%$.

Views of prospective teachers on the proposition in the $3^{\text {rd }}$ question that "scientists conduct their scientific classification according to specific scientific methods" do not demonstrate any significant differences according to gender. $85 \%$ of both male and female prospective teachers argued that methods of scientific classification are not limited and that scientists must use many different methods, while $13 \%$ of them held that it would be better to continue using previously used methods.

Prospective teachers' responses to the $4^{\text {th }}$ question on "mutability of scientific knowledge" do not differ significantly between genders. The proportion of male prospective teachers who supported the opinion that scientific knowledge can change was $56 \%$, while the proportion of females were $42.6 \%$. These results can be interpreted as male prospective teachers' perceptions of the mutability of scientific knowledge may slightly exceed females. 
It was determined that prospective teachers' views on the $5^{\text {th }}$ question and the "relations between hypotheses, theories and laws" do not differ much on the basis of gender differences. $86 \%$ of both male and female prospective teachers have the opinion that "scientific ideas develop from hypotheses into theories, while theories evolve into laws". These results demonstrate that prospective teachers have adopted the prevalent paradigm on stages of scientific research methodology.

With respect to the "the role of assumptions in the development of new theories and laws", responses of prospective teachers demonstrate significant differences according to gender $\left(\chi^{2}(2)=11.1 ; p<0.01\right)$. More than half of the male prospective teachers argue that assumptions proposed by scientists to understand nature must be true, while female prospective teachers do not hold such a view.

Prospective teachers" views on "the criterion of superiority of scientific knowledge" as they are sought in the $7^{\text {th }}$ and $8^{\text {th }}$ questions do not pose significant differences in terms of gender. The majority of both male and female prospective teachers claim that scientists seek to reveal the beauty, elegance and simplicity of nature in their scientific studies. The proportion of prospective teachers who are defending that the works of scientists are very complex and that they do not seek to reveal natural beauty is approximately $20 \%$.

When responses of prospective teachers to the $9^{\text {th }}$ question on "the role of scientific method in scientific research" were examined, it was seen that they did not reflect variations based on gender. Majority of both male and female prospective teachers defended that scientists follow the steps of scientific method. A smaller rate of them propounded that a good scientist should employ different methods.

Prospective teachers' views on the $10^{\text {th }}$ question about "the role of communication in scientific method" did not any show significant difference according to gender. The vast majority of male and female prospective teachers think that logical structure prepared by scientists in their scientific publications is not a serious or significant feature of their work. But male prospective teachers propounded the view "although scientists do not conduct their research in a logical order, they present the articles they publish in journals in a logical order" with a higher percentage of female prospective teachers.

Responses to the $11^{\text {th }}$ question about "uncertainty and accuracy of scientific information" also did not differ significantly in terms of gender. 9/10 of both male and female prospective teachers believe that scientific studies should not be considered as absolutely true, and that there is necessarily a certain amount of errors. Students who do not support this view claim that the mathematical estimates are absolutely correct. According to these results, it may be suggested that the mutability of scientific knowledge was widely adopted by the majority of prospective teachers

The $12^{\text {th }}$ question on the "logical evaluation of scientific studies" did not provide responses that varied significantly according to gender. Around $70 \%$ of male and female prospective teachers believe that when there are not enough scientific findings, the proposed information will not be valid. $25 \%$ of the prospective teachers claim that if scientists reach a finding and are defending this idea, then it must be accepted as true. This result shows that in prospective teachers' viewpoint, scientific studies should be supported with solid evidence.

It was observed that responses of prospective teachers on "basic assumptions of all sciences" in the $13^{\text {th }}$ question do not differ significantly in terms of gender. $54 \%$ of male and female prospective teachers have the opinion that the natural world cannot be explained by supernatural forces, while approximately $42 \%$ claim that scientists should be able to accept that supernatural forces affect the natural world. 
Prospective teachers that are directed to the $14^{\text {th }}, 15^{\text {th }}$ and $16^{\text {th }}$ questions about the "epistemological structure of scientific knowledge" did not present different opinions that reflect gender differences. While their views on this issue did not differ in a major way on $14^{\text {th }}$ and $15^{\text {th }}$ questions, significant differences are observed in $16^{\text {th }}$ question $\left(\chi^{2}(2)=7.0 ; p<\right.$ $0.05)$. The vast majority of both male and female prospective teachers claim that scientists invent the laws and hypotheses. $17 \%$ of prospective teachers claim that scientists do not invent such knowledge, but depend on previously revealed uses of held information. While the opinions of male and female prospective teachers about the revealing of scientific theories seems to have similar rates, the proportion of male prospective teachers who did not have an idea on the issue is higher than females. This situation demonstrates that responses to these specific questions by prospective teachers present significant differences.

The $17^{\text {th }}$ question that was related to "the paradigm of interdisciplinary concepts" did not yield responses by prospective teachers that differed according to gender. About $3 / 5$ of male and female prospective teachers support the idea that perspectives of scientists vary according to their field. The rate of those who believe that scientists' views should not change according to their field of work is $35 \%$. This result can be interpreted so that prospective teachers support the idea that different methods should be used in science.

Prospective teachers' responses to $18^{\text {th }}$ question about the "compatibility of interdisciplinary concept" vary significantly according to gender $\left(\chi^{2}(2)=7.2 ; p<0.05\right)$. Male and female prospective teachers largely support the idea that scientists working in different areas look at the same event from different angles. But support rate by males is higher than females. While every female present some idea on the issue, $6 \%$ of males presented no ideas.

\section{Conclusion and Suggestions}

In this part, the results on understanding levels of the prospective teachers on the nature of science are compared with results of different researches and in this regard suggestions are presented.

Based on these research results, support for assumptions of positivist philosophy among prospective teachers could be argued to be much higher than support for the subjectivist approach. The following approaches or inclinations widely held by more than half of prospective teachers are considered here as an important evidence of the analysis of these results: considering experimental results more scientific than other types of findings; being confident in the requirement that hypotheses should be verified by experiments; believing that science should be more evidence-based; lack of support for views on the mutability of science; arguing that there will be no science without hypotheses; having a tendency for inductionism or falsificationism; claiming that scientific method has rigid solid steps; purporting that the presentation of scientific studies should logical; faith in the necessity of logical questioning for scientific knowledge; considering science as the only source of truth in explaining natural phenomena; tendency to see scientists as discoverers of a knowledge that is already present. Besides, it has been determined that viewpoints of prospective science teachers on the nature of science does not vary with respect to their grade level; that more than half of prospective teachers in every grade level hold assumptions positivist of philosophy; and that prospective teachers from lesser grade levels have a slightly higher rate of support for assumptions of the positivist paradigm. In the study conducted by Kang, Scharmann and Noh (2005) in Korea, the majority of students held empiricist views about the NOS and their opinions did not differ significantly according to their grade level. Another study has claimed that a large portion of high school students are not well-equipped or instructed on the nature of scientific knowledge (Kılıç, Sungur, Çakıroğlu and Tekkaya, 2005). The study of Balkı, Çoban and Aktaş (2003) on second level primary education 
demonstrates that students hold similar ideas regarding the NOS; for instance, they believe that becoming a scientist requires having special skills. These results can be evaluated in the claim that students have similar views on the NOS, irrespective of their grade levels.

Along these results, prospective science teachers who supported subjectivist approaches have also been identified, albeit at a lower rate. Holding that scientific knowledge may change; that science produces not only quantities but also qualities; that errors may interfere in the results of scientific studies; that it is impossible for science to explain all the phenomena in the world; that there may be different paradigms and interpretations in different branches of science, some of these prospective teachers could be ascertained as supporters of subjectivist philosophy. The results Taşar (2002) sets forth in his studies demonstrate that prospective science teachers have been developing positive profiles with respect to the foundations of the NOS. As our study also demonstrates, the fact that prospective scientists in higher grade levels hold the traditionalist view on the NOS less enthusiastically than those in lesser grade levels, which could be explained by positive development of prospective teachers during the process of education. But since this rate remains on relatively very low levels, it has been ascertained through the results of this and other studies in the existing literature on the subject that prospective science teachers are inadequate for properly understanding the nature of science in general.

These results could also be interpreted through the claim that prospective teachers support more traditionalist approaches to science and also that they lack proper knowledge about the nature of science. When examined, it will be clear that the international literature on the subject contains both positive and negative results on the views of prospective teachers on the NOS. Discenna and Howse (1998) claimed that the 22 prospective teachers they studied on held the traditional view. Aguirre, Haggerty and Linder (1990) conducted a study on the education and learning of the NOS with 74 American prospective science teachers who provided responses to 11 open-ended questions; the analysis of these responses led to the conclusion that prospective science teachers do not have a sound knowledge on the NOS. A recent study by Aslan, Yalçın and Taşar (2009) also indicated that views of prospective science teachers about the nature of science were insufficient.

On the other hand, Abd-El-Khalick and Lederman (1998) stated that prospective science teachers have a consistent and contemporary perspective about the NOS. Cheung and Toh (1990) claimed that the views of prospective teachers and intern elementary school teachers gradually evolve into a more novel and contemporary point of view. In a US-based study, views of prospective teachers in America are sorted into an ordinal scale ranging from "inadequate" to "contemporary" and at the end of the study it has been observed that prospective teachers predominantly had a contemporary view (Abd-El-Khalick and Lederman, 1998). Pomeroy (1993) conducted another study comparing views of scientists on the NOS with those of first and second grade primary school teachers. The study spanned views of 71 scientists and 109 teachers. As a result, scientists turned out to be holding the traditional view, while most of the teachers had less traditional views. Considering the results of this study in comparison to the existing literature, it could be argued that prospective science teachers are inadequate in understanding the NOS, but gradual advance into higher grade levels during their education leads to a (albeit partial) reduction of their inadequate views, which is consistent with the results of the studies mentioned above. This is because prospective teachers (like the majority of scientists and philosophers of science) think that scientific studies search for the truths about the world. These views of prospective teachers are consistent with the general opinion of many science educators (Matthews, 1998; Eflin, Glennan and Reisch, 1999). 
Another result obtained in this study is that gender differences among prospective teachers are not significantly related to preference of positivist or subjectivist philosophy. More than half of both male and female prospective teachers defend the basic assumptions of positivist philosophy. It has also been ascertained that female prospective teachers display more resolution in defending their positions than their male counterparts. Based on his own research, Wood (1972) has claimed that gender does not have a significant effect on ways of understanding the NOS. Another study conducted by Braisher and colleagues (2005) has demonstrated that approaches of scientists towards the NOS did not differentiate based on gender. Claiming that there was a male-dominated scientific community prior to $1970 \mathrm{~s}$, Lederman and colleagues (2002) argue that women started to attain important roles in later decades. The study of conducted by Terzi (2005) indicates that social science students and females have a more positivist understanding of science than (respectively) natural science students and males.

Another remarkable consequence of this study is the finding that vast majority of prospective teachers hold two misguided opinions. The first involves the belief that there are universal scientific methods, while the latter presupposes hierarchical relations between hypotheses, theories and laws. These two concepts reveal resistance to changes towards the NOS. The vast majority of prospective teachers claim that science should be conducted with universal methods (article 9) and written in a standard format so that it would be convenient for communicating with other scientists (article 10). These results are consistent with Chen's (2001) study. While $87 \%$ of prospective teachers in Chen's study held that hypotheses become theories and that theories evolve into laws, prospective teachers in this study also supported these views in a very similar rate.

\section{Suggestions for Practitioners}

Based on the results of this study, it has been observed that prospective teachers have certain misconceptions about the NOS. One of the most important reasons for this is our system of training science teachers. Attributing lack of understanding on the NOS in our country to the problematic nature of science education, Bağc1-Kılıç (2002) argue that it would be much productive to engage students through experiments, rather than through presentations in classes. A study conducted by Tsai (2006) clearly shows that science courses and courses for teachers and prospective teachers during in-service and pre-service processes are very influential, their ideas being significantly changed. In this study, why and how to teach NOS has been put forward explicitly. For example, it would be very effective to include NOS as a part of science education, and to define a new class course with theoretical and practical lessons for processing special events in a context of thinking in depth. Palmquist and Finley (1997) study claim that prospective teachers have very little training about the nature of science and that appropriate training requirements can be achieved by creating significant improvements in this regard. Our country restructured teacher education program in 2005 with a new teaching curriculum and the new "History and Nature of Science" course introduced thereby will be an important contribution in this regard. But that since the content of such a course is not reserved exclusively for science; introduction of this course on other program will provide a definitely positive contribution to the general perspective of our society on science

Another finding that comes to the fore with respect to the understanding of the NOS is that prospective teachers do not have a clear grasp of the relationship between hypotheses, theories and laws. As also determined in this study, prospective teachers have a hierarchical understanding of these concepts, claiming that scientific work is conducted accordingly. In order to correct these ideas, concepts of hypotheses, theories and laws must be learned in a 
proper and concrete way. This may be possible by integrating actual stories by (or about) scientists in courses on how to do research and reach results. A guest scientist may be invited in order to learn about his work; or specific circumstances may be presented to prospective teachers in order to be given the opportunity of working with the sensitivity of an actual scientist. In addition, whether or not the contents of the textbooks accurately convey the NOS will have a major effect in that regard. Koray, Bahadır and Geçgin (2006) claimed that existing textbooks are inadequate in terms of skills of scientific processing. Therefore, it is of vital importance for the commission that prepares the curriculum or for the textbook authors to provide corrective information in textbooks that would prioritize the NOS and reduce misperceptions that are widespread in scientific studies, which will provide immediate contributions in the short term.

\section{References}

Abd-El-Khalick, F., Bell, R.L., \& Lederman, N.G. (1998). The nature of science and instructional practice: Making the unnatural natural. Science Education, 82, 417-436.

Abd-El-Khalick, F., \& Lederman, N.G. (1999, September). Success of the attempts to improve science teachers' conceptions of the nature of science: A review of the literature. The $5^{\text {th }}$ International History, Philosophy and Science Teaching Conference, Como, Italy.

Aikenhead, G. S., \& Ryan, A.G. (1992). The development of a new instrument: "Views on Science- Technology-Society" (VOST). Science Education, 76, 477-491.

Aguirre, J. M., Haggerty, S. M., \& Linder, C. J. (1990). Student-teachers' conceptions of science, teaching and learning: A case study in preservice science education. International Journal of Science Education, 12, 381-390.

Akerson, V.L., Buzzeli, C.A., \& Donnelly, L.A. (2010). On the nature of teaching nature of science: Preservice early childhood teachers' instruction in preschool and elementary settings. Journal of Research in Science Teaching, 47(2), 213-233.

Aslan, O., Yalçın, N., \& Taşar, M.F. (2009). The views oft he teachers of the science and technology on the nature of science. Ahi Evran University Journal of Education Faculty, 10(3), 1-8.

Bağc1-Kılıç, G. (2002). World and science teaching in Turkey. Fifth National Congress of Science and Mathematics Education, Middle East Technical University, Ankara, Turkey.

Balkı, N., Çoban, A.K., \& Aktaş, M. (2003). View about elementary students' science and scientists. Uludăg University Journal of Education Faculty, 17(1), 11-17.

Bell, R.L., \& Lederman, N.G. (2003). Understandings of the nature of science and decision making on science and technology based issues. Science Education, 87, 352-377.

Bell, R.L., Lederman, N.G., \& Abd-El-Khalick, F. (2000). Developing and acting upon one's conception of the nature of science: A follow-up study. Journal of Research in Science Teaching, 3(6), 563-581.

Berberoğlu, G., \& Kalender, İ. (2005). Investigation of student achievement across years, school types and region: The SSE and PISA analyses. Journal of Educational Science and Practice, 4(7), 24-35. 
Bianchini, J.A., \& Colburn, A. (2000). Teaching the nature of science through inquiry to prospective elementary teachers: A tale of two researchers. Journal of Research in Science Teaching, 37(2), 177-209.

Braisher, T.L., Symonds, M.R.E., \& Gemmell, N.L. (2005). Publication success in nature and science is not gender dependent. BioEssays, 27, 858-859.

Chen, S. (2001). Prospective teachers' views on the nature of science and science teaching. $\mathrm{PhD}$ Thesis, Department of Curriculum and Instruction, Indiana University.

Cheung, K. C., \& Toh, K. A. (1990). In the eyes of the beholder: Beginning teachers' conception of the nature of science and science teaching. Singapore: The Annual Conference of the Educational Research Association.

Discenna, J. L., \& Howse, M. A., (1998). Biology and physics students' beliefs about science and science learning in non-traditional classrooms. San Diego, CA: The Annual Meeting of American Educational Research Association.

Donnelly, J. (1999). Interpreting differences: The educational aims of teachers of science and history, and their implication. Journal of Curriculum Studies, 31, 17-41.

Eflin, J. T., Glennan, S., \& Reisch, G. (1999). The Nature of science: A perspective from the philosophy of science. Journal of Research in Science Teaching. 36, 107-116.

Gallagher, J.J. (1991). Prospective and practicing secondery school teachers'knowledge and beliefs about the philosophy of science. Science Education, 75, 121-133.

Kang, S., Scharmann, C. L., \& Noh, T. (2005). Examining students' views on the nature of science: Results from Korean 6th, 8th, and 10th graders. Science Education, 89, 314334.

Kılıç, K., Sungur, S., Çakıroğlu, J., \& Tekkaya, C. (2005). Ninth grade students' understanding of the nature of scientific knowledge. Hacettepe University Journal of Education Faculty, 28, 127-133.

Koray, Ö., Bahadır, H., \& Geçgin, F. (2006). The states of being represented of science process's skills in the course books of chemistry and chemistry curriculums at the class 9th. Karaelmas University Journal of Social Science, 2(4), 147-156.

Kuhn, T. (1982). Bilimsel devrimlerin yapısı [The structure of scientific revolutions]. ( $\mathrm{N}$. Kuyaş, Trans.), İstanbul: Alan Publishing.

Kurt, H., Kaya, B., Ateş, A., \& Kılıç, S. (2009). The biological literacy of biology teacher candidates. Selçuk University Journal of Ahmet Keleşoğlu Education Faculty, 27, 1730 .

Lederman, N.G. (1992). Students' and teachers' conceptions of the nature of science: A review of the research. Journal of Research in Science Teaching, 29, 331-359.

Lederman, N.G., Abd-El-Khalick, F., Bell, R.L. \& Schwartz, R.S. (2002). Views of nature of science questionnaire: Toward valid and meaningful assessment of learners' conceptions of nature of science. Journal of Research in Science Teaching, 39(6), 497521.

Matthews, M. R. (1998). In defense of modest goals when teaching about the nature of science. Journal of Research in Science Teaching. 35, 161-174. 
McComas, W.F., Clough, M.P., \& Almazroa, H. (2006). The role and character of the nature of science in science education. In J. Gilbert (Ed.), Science education: Major themes in education, (p. 28-58), Abington: Routledge.

Meichtry, Y. J. (1993). The impact of science curricula on students views about the nature of science. Journal of Research in Science Teaching, 30(5), 429-443.

Palmquist, B.C., \& Finley, F.N. (1997). Preservice teachers' views of the nature of science during a postbaccalaureate science teaching program. Journal of Research in Science Teaching, 34(6), 595-615.

Pomeroy, D. (1993). Implications of teachers' beliefs about the nature of science: Comparison of the beliefs of scientist, secondary science teachers, and elementary teachers. Science Education, 77, 261-278.

Renner, J.W. \& Marek, E.A. (1990). An educational theory base for science teaching. Journal of Research in Science Teaching, 27(3), 241-246.

Snow, C.P. (2001). İki kültür [The two cultures]. (T. Birkan, Trans), Ankara: Tubitak Publishing.

Taşar, M.F. (2002). The views about science survey. Fifth National Congress of Science and Mathematics Education, Middle East Technical University, Ankara, Turkey.

Terzi, A.R. (2005). A research on scientific epistemological beliefs of university students. Afyon Kocatepe University Journal of Social Science, 7(2), 288-311.

Tsai, C.C. (2002). Nested epistemologies: Science teachers' beliefs af teaching, learning and science. International Journal of Science Education, 24, 771-783.

Tsai, C.C. (2006). Reinterpreting and reconstructing science: Teachers' view changes toward the nature of science by courses of science education. Teaching and Teacher Education, $22,363-375$.

Tunç-Şahin, C., \& Köksal, M.S. (2010). How are the perceptions of high school students and teachers on NOS as a knowledge type presented in schools in terms of "importance" and "interest"? International Journal of Environmental \& Science Education, 5(1), 105126

Turgut, H. (2009). Prospective science teachers' conceptions about scientific knowledge and method. Journal of Turkish Educational Sciences, 7(1), 165-184.

Wood, R.L. (1972). University education student's understanding of the nature and processes of science. School Science and Mathematics, 72(1), 73-79. 